\title{
Enjoy Carefully: The Multifaceted Role of Vitamin E in Neuro-Nutrition
}

\author{
Liesa Regner-Nelke ${ }^{1, *}$, Christopher Nelke ${ }^{1}$, Christina B. Schroeter ${ }^{1}$, Rainer Dziewas ${ }^{2}$, Tobias Warnecke ${ }^{3}$ (D), \\ Tobias Ruck ${ }^{1}$ and Sven G. Meuth ${ }^{1}$
}

1 Department of Neurology, Medical Faculty, Heinrich Heine University Düsseldorf, 40225 Düsseldorf, Germany; christopherjannik.nelke@med.uni-duesseldorf.de (C.N.); christinabarbara.schroeter@med.uni-duesseldorf.de (C.B.S.); tobias.ruck@med.uni-duesseldorf.de (T.R.); meuth@uni-duesseldorf.de (S.G.M.)

2 Department of Neurology, Klinikum Osnabrück, Am Finkenhügel 1, 49076 Osnabrück, Germany; rainer.dziewas@klinikum-os.de

3 Department of Neurology with Institute of Translational Neurology, University Hospital Münster, Albert-Schweitzer-Campus 1, 48149 Münster, Germany; tobias.warnecke@ukmuenster.de

* Correspondence: liesa.regner-nelke@med.uni-duesseldorf.de

Citation: Regner-Nelke, L.; Nelke, C.; Schroeter, C.B.; Dziewas, R.;

Warnecke, T.; Ruck, T.; Meuth, S.G. Enjoy Carefully: The Multifaceted Role of Vitamin E in Neuro-Nutrition. Int. J. Mol. Sci. 2021, 22, 10087. https://doi.org/10.3390/ ijms221810087

Academic Editor: Simona Serini

Received: 26 August 2021

Accepted: 15 September 2021

Published: 18 September 2021

Publisher's Note: MDPI stays neutral with regard to jurisdictional claims in published maps and institutional affiliations.

Copyright: (C) 2021 by the authors Licensee MDPI, Basel, Switzerland. This article is an open access article distributed under the terms and conditions of the Creative Commons Attribution (CC BY) license (https:/ / creativecommons.org/licenses/by/ $4.0 /)$.

\begin{abstract}
Vitamin E is often associated with health benefits, such as antioxidant, anti-inflammatory and cholesterol-lowering effects. These properties make its supplementation a suitable therapeutic approach in neurodegenerative disorders, for example, Alzheimer's or Parkinson's disease. However, trials evaluating the effects of vitamin E supplementation are inconsistent. In randomized controlled trials, the observed associations often cannot be substantiated. This could be due to the wide variety of study designs regarding the dosage and duration of vitamin E supplementation. Furthermore, genetic variants can influence vitamin E uptake and/or metabolism, thereby distorting its overall effect. Recent studies also show adverse effects of vitamin E supplementation regarding Alzheimer's disease due to the increased synthesis of amyloid $\beta$. These diverse effects may underline the inhomogeneous outcomes associated with its supplementation and argue for a more thoughtful usage of vitamin $\mathrm{E}$. Specifically, the genetic and nutritional profile should be taken into consideration to identify suitable candidates who will benefit from supplementation. In this review, we will provide an overview of the current knowledge of vitamin E supplementation in neurodegenerative disease and give an outlook on individualized, sustainable neuro-nutrition, with a focus on vitamin E supplementation.
\end{abstract}

Keywords: vitamin E; neurodegenerative diseases; nutrition; vitamin E supplementation; Alzheimer's disease; personalized medicine

\section{Introduction}

Vitamin E was first discovered by the American endocrinologist and anatomist Herbert. M. Evans, together with his assistant Katherine S. Bishop [1]. The isolated substance, later termed vitamin E, describes a group of compounds consisting of four tocopherol (TP)and four tocotrienol (TT)-derivatives. They all share a chromanol ring as their structural basis and are therefore termed tocochromanols. The chromanol ring is hydroxylated in position 6 and, due to the methylation of the ring, $\alpha-, \beta-, \gamma$ - and $\delta$-forms can be differentiated (Figure 1). TPs and TTs are classified according to their side chain: TPs contain one saturated fatty acid, whereas TTs contain a triple unsaturated fatty acid (Figure 1). The biological properties of vitamin E compounds are mainly determined by their structure. In humans, $\alpha$-TP is the biologically most active form that binds with highest affinity to the $\alpha$-tocopherol-transfer protein ( $\alpha$-TTP) [2]. $\alpha$-TTP is a soluble protein found in the cytosol of hepatocytes in humans that acts to transport TPs between membrane vesicles, allowing for the distribution of vitamin E [3]. 

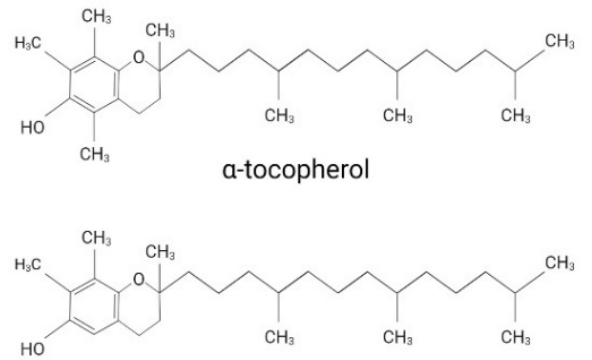

$\beta$-tocopherol

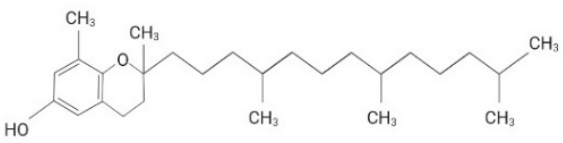

Y-tocopherol

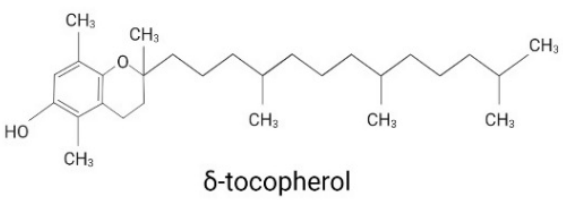

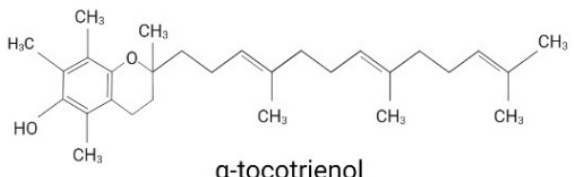

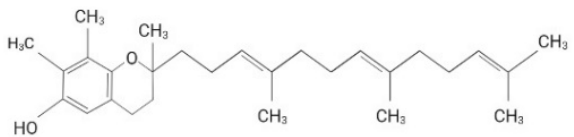

$\beta$-tocotrienol

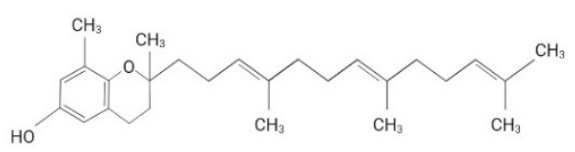

y-tocotrienol

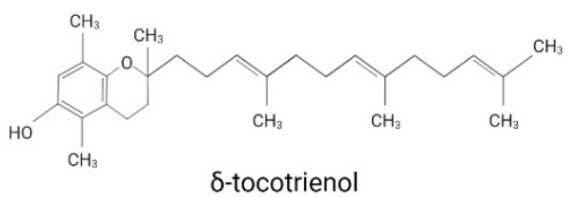

Figure 1. The structures of tocopherol- and tocotrienol- derivatives.

The definition of vitamin $\mathrm{E}$ and which derivates should be associated with this term are still under discussion. While vitamin $\mathrm{E}$ is extensively used as an umbrella term for different TP- and TT-forms, some authors use it as a synonym for $\alpha$-TP. Azzi et al. justify the use of vitamin $\mathrm{E}$ as a synonym for $\alpha$-TP by considering the classification of vitamins, which describes them as a group of substances essential for normal metabolism with deficiencies leading to disorders treatable by supplementation [4]. Accordingly, only $\alpha$-TP should be named vitamin E, since it is the only form that has been shown to prevent the rare, inherited neurodegenerative disorder ataxia with vitamin E deficiency (AVED), which is caused by mutations in gene encoding for $\alpha$-TTP, alpha tocopherol transfer protein (TTPA) [4,5]. However, since TPs and TTs are generally both implied when using the term vitamin E the scientific literature, we will also use vitamin $\mathrm{E}$ as an umbrella term in this review.

Considering the consequences of vitamin E deficiency-ataxia, dysarthria and neuromuscular disorders [6] - it is clear that this substance plays an important role in the central and peripheral nervous systems. Of interest, abetalipoproteinemia, a disorder characterized an inability to absorb fat and thereby profound the deficiency of chylomicrons, low-density lipoprotein (LDL) and very low-density lipoprotein (VLDL), all of which, being necessary for vitamin $\mathrm{E}$ absorption, result in ataxic neuropathy, retinal pigmentation, areflexia, and loss of proprioception [7]. Furthermore, equine neuroaxonal dystrophy/equine degenerative myeloencephalopathy, a neurodegenerative disorder affecting foals that resembles AVED, is associated with vitamin E deficiency, but is not associated with mutations in TTPA, such as is the case for AVED [8]. Interestingly, Kono et al. describe a case of juvenile spinocerebellar ataxia resulting from mutations in the phospholipid transfer protein (PLTP) gene, as well as TTPA [9].

Particularly in neurodegenerative disorders, vitamin E demonstrates notable benefits due to its antioxidant, anti-inflammatory and cholesterol-lowering properties [10]. Vitamin E supplementation as a therapy, particularly for neurodegenerative disorders, appears feasible and has been widely investigated, both in vitro and in vivo [11,12]. However, it has so far not been established in the prevention or treatment of these disorders, given the incoherent and sometimes contradictive results of interventional studies, and the apparent adverse effects of vitamin E supplementation [13]. Following recent insights into genetic polymorphisms, which play a crucial role in the metabolism of vitamin E, a new approach applying personalized medicine has emerged [14]. In this review, we 
will discuss the advantageous and disadvantageous effects of vitamin $\mathrm{E}$ in the context of neurodegenerative disease, as well as the factors that should be taken into consideration when tailoring personalized vitamin E supplementation strategies.

\section{Characteristics of Vitamin $E$ in the Context of Neurodegenerative Diseases}

Structural differences give rise to biological variability among vitamin E derivatives (Table 1). These differences are important when considering the disease-modifying and preventive effects of supplementation.

Table 1. Characteristics of vitamin E-derivates.

\begin{tabular}{|c|c|c|c|}
\hline Vitamin E & & Biological Properties & Refrences \\
\hline \multirow[t]{6}{*}{ Tocopherols } & & Antioxidation & [15-17] \\
\hline & & Cholesterol-lowering & {$[18,19]$} \\
\hline & $\alpha$-Tocopherol & Anti-inflammation & {$[17,20,21]$} \\
\hline & $\gamma$-Tocopherol & Anti-inflammation & {$[21,22]$} \\
\hline & & Anti-neoplastic & {$[23,24]$} \\
\hline & $\delta$-Tocopherol & Anti-neoplastic & [25] \\
\hline \multirow[t]{9}{*}{ Tocotrienols } & & Antioxidation & {$[15,26]$} \\
\hline & & Cholesterol-lowering & [27-29] \\
\hline & & Anti-inflammation & {$[16,30]$} \\
\hline & & Anti-neoplastic & {$[24,31-33]$} \\
\hline & $\alpha$-Tocotrienol & Immunostimulation & [34-36] \\
\hline & & Neuroprotection & {$[37,38]$} \\
\hline & $\beta$-Tocotrineol & Neuroprotection & [39] \\
\hline & $\gamma$-Tocotrienol & Neuroprotection & [38] \\
\hline & $\delta$-Tocotrienol & Immunostimulation & {$[40]$} \\
\hline
\end{tabular}

Table 2. Overview of relevant vitamin E-related clinical trials and results in neurodegenerative disorders.

\begin{tabular}{|c|c|c|c|c|c|}
\hline \multicolumn{6}{|c|}{ Vitamin E Related Clinical Trials in Neurodegenerative Disorders } \\
\hline & Subject & Supplementation & Duration & Results & Reference \\
\hline \multirow[t]{3}{*}{$\begin{array}{l}\text { Alzheimer's } \\
\text { disease }\end{array}$} & $57 \mathrm{AD}$ patients & $\begin{array}{c}800 \text { I/dU vitamin E, } \\
\text { Placebo }\end{array}$ & 6 months & $\begin{array}{c}\text { Differentiation } \\
\text { responders/non-responders; } \\
\text { responders showed lower } \\
\text { oxidized glutathione levels } \\
\text { than non-responders; } \\
\text { cognitive status decreased in } \\
\text { non-responders }\end{array}$ & [41] \\
\hline & $\begin{array}{l}613 \text { patients with } \\
\text { mild to moderate } \\
\text { AD }\end{array}$ & $\begin{array}{c}2000 \mathrm{IU} / \mathrm{d} \alpha \text {-tocopherol, } \\
20 \mathrm{mg} / \mathrm{d} \text { memantine, } \\
2000 \mathrm{IU} / \mathrm{d} \alpha \text {-tocopherol }+20 \\
\text { mg/d } \\
\text { memantine, } \\
\text { Placebo }\end{array}$ & 6 months & $\begin{array}{l}\alpha \text {-tocopherol compared with } \\
\text { placebo resulted in slower } \\
\text { functional decline }\end{array}$ & [42] \\
\hline & $\begin{array}{l}341 \text { moderate AD } \\
\text { patients }\end{array}$ & $\begin{array}{c}10 \mathrm{mg} / \mathrm{d} \text { monoamine oxidase } \\
\text { inhibitor, } 2000 \mathrm{IU} / \mathrm{d} \\
\alpha \text {-tocopherol, Selegiline and } \\
\alpha \text {-tocopherol, Placebo }\end{array}$ & 2 years & $\begin{array}{l}\text { In patients with moderately } \\
\text { severe impairment, } \\
\alpha \text {-tocopherol slows } \\
\text { progression }\end{array}$ & [43] \\
\hline \multirow[t]{2}{*}{$\begin{array}{l}\text { Parkinson's } \\
\text { disease }\end{array}$} & 60 PD patients & $\begin{array}{c}400 \text { IU / d vitamin } \mathrm{E}+1000 \\
\mathrm{mg} / \mathrm{d} \text { omega- } 3 \text { fatty acids } \\
\text { from flaxseed oil plus } \\
\text { supplements, } \\
\text { Placebo }\end{array}$ & 12 weeks & $\begin{array}{l}\text { Favorable effects on UPDRS, } \\
\text { hs-CRP, TAC, GSH, and } \\
\text { markers of insulin metabolism }\end{array}$ & [44] \\
\hline & 800 PD patients & $\begin{array}{l}2000 \mathrm{IU} / \mathrm{d} \text { tocopherol +/or } \\
10 \mathrm{mg} / \mathrm{d} \text { deprenyl, Placebo }\end{array}$ & 2 years & $\begin{array}{l}\text { Tocopherol did not extend the } \\
\text { time to levodopa therapy }\end{array}$ & [45] \\
\hline
\end{tabular}


Table 2. Cont.

\begin{tabular}{|c|c|c|c|c|c|}
\hline \multicolumn{6}{|c|}{ Vitamin E Related Clinical Trials in Neurodegenerative Disorders } \\
\hline & Subject & Supplementation & Duration & Results & Reference \\
\hline $\begin{array}{l}\text { Huntington's } \\
\text { disease }\end{array}$ & 73 HD patients & 3000 IU /d $\alpha$-tocopherol & 1 year & $\begin{array}{l}\text { Selective therapeutic effect on } \\
\text { neurologic symptoms for } \\
\text { patients in the early course of } \\
\text { the disorder }\end{array}$ & [46] \\
\hline \multirow[t]{2}{*}{$\begin{array}{l}\text { Amyotrophic } \\
\text { lateral } \\
\text { sclerosis }\end{array}$} & $\begin{array}{l}160 \text { patients with } \\
\text { either probable or } \\
\text { definite ALS }\end{array}$ & $\begin{array}{c}5000 \mathrm{mg} / \mathrm{d} \alpha \text {-tocopherol, } \\
\text { Placebo } \\
\text { as add on to riluzol }\end{array}$ & 18 months & $\begin{array}{l}\text { No significant effect regarding } \\
\text { survival rates, calculated time } \\
\text { to death, tracheostomy, or } \\
\text { permanent assisted } \\
\text { ventilation }\end{array}$ & [47] \\
\hline & 289 ALS patients & $\begin{array}{l}500 \mathrm{mg} \alpha \text {-tocopherol, } \\
\text { Placebo } \\
\text { as add on to riluzol }\end{array}$ & 12 months & $\begin{array}{l}\alpha \text {-tocopherol group was less } \\
\text { likely progressed from state A } \\
\text { to more severe state B }\end{array}$ & [48] \\
\hline
\end{tabular}

Abbreviations: AD, Alzheimer's disease; PD, Parkinson's disease; HD, Huntington's disease; ALS, Amyotrophic lateral sclerosis; UPDRS, unified Parkinson's disease rating stage; hs-CRP, high-sensitivity C-reactive protein; TAC, total antioxidant capacity; GSH, glutathione.

$\alpha$-TP has previously been in scientific focus due to its high bioavailability [49]. TPs are known to have antioxidant effects by increasing the activity of antioxidant enzymes and free radical scavenging. They can therefore interrupt free radical chain reactions. The free hydroxyl group on the aromatic ring is responsible for these antioxidant properties, as it is capable of scavenging free radicals, resulting in a relatively stable vitamin E radical. This radical can be reduced by ascorbic acid, which is then regenerated by glutathione [50].

Given its antioxidant properties, vitamin $\mathrm{E}$ has been considered an attractive therapeutic agent for the prevention and treatment of neurodegenerative diseases, such as Alzheimer's (AD) and Parkinson's disease (PD), where oxidative stress is an important pathophysiological driver [51,52]. Due to structural differences, TTs exert comparable or even more pronounced antioxidative effects, since they are distributed more homogeneously in the lipid membrane, and because recycling from chromanoxyl radicals is more efficient, thereby providing better reaction conditions, due to the stronger disordering of membrane lipids [53].

In addition, certain TPs and TTs exert anti-inflammatory effects through various methods of interference with the cellular and humoral immune systems. The antioxidative effects of TPs and TTs are intrinsically linked to their anti-inflammatory properties, since oxidative stress is a part of the inflammatory response [54]. However, certain effects are independent of these antioxidative properties. As such, vitamin E interferes with the inflammatory response at different levels, e.g., via transcription factors, signaling cascades, and the synthesis of signaling molecules [55]. $\alpha-, \gamma$ - and $\delta$-TP have been shown to control Nrf-2 and NfkB signaling pathways in Caco-2 intestinal cells, which are crucial for the inflammatory response [56]. Of note, Jian et al. demonstrated that the suppression of prostaglandin synthesis through $\alpha-, \gamma$ - and $\delta$-TP, by direct competitive inhibition of cyclooxygenase- 2 (COX-2) with $\alpha$-TP, inhibits tumor necrosis factor $\alpha$ (TNF- $\alpha$ ) [57]. A meta-analysis of randomized controlled trials revealed a significant reduction of C-reactive protein (CRP) levels in groups supplemented with $\alpha$ - and $\gamma$-TP [58]. An additional meta-analysis suggested an association between $\alpha$-TP-supplementation and decreased interleukin 6 (IL-6) serum levels [59].

However, the biological profile of vitamin $\mathrm{E}$ is not only restricted to the mediation of anti-inflammatory effects, but also characterized by immune-stimulatory properties, such as amplification of T-cell function [60]. Consistent with this, dietary in vivo studies suggested improved T-cell mediated functions, such as interleukin 2 (Il-2) production and $\mathrm{T}$ helper activity, in response to vitamin E supplementation [61,62].

Aside from these immunomodulatory effects, antineoplastic properties have been observed for vitamin E in case-control studies, as well as in interventional studies, but 
without reaching a definite conclusion [63-65]. Since most of these studies were performed with $\alpha-\mathrm{TP}$, the conflicting results shifted the focus to other vitamin E compounds. As such, a $\gamma$-TP-rich TP mixture demonstrated inhibitory potential on lung, colon, prostate, and breast cancer cell lines $[22,23,25,66]$. In mice with an induced lung tumor, application of the TP mixture resulted in reduced tumor burden, volume and multiplicity. Lower levels of DNA damage and thereby DNA repair, as well as increased apoptosis, were also observed [67]. Furthermore, a recent study suggested potent cytotoxic effects on brain cancer cells through $\gamma$-TT combined with the indole alkaloid jerantinine [24].

The cholesterol-lowering properties of the vitamin E compounds further demonstrate their use as therapeutic substances in chronic disease [68]. In 1986, Qureshi et al. isolated a cholesterol-lowering substance out of barley, later found to be $\alpha$-TP [18]. In in vivo as well as human interventional studies, vitamin E compounds produced an improved serum cholesterol profile. This effect was partly attributed to the inhibition of HMG-CoAreductase, which is unique to TPs. The comparison of different vitamin E compounds revealed a 30-fold higher inhibition of cholesterol biosynthesis for $\gamma$-TT compared to $\alpha$-TP $[27,69]$. In human neuroblastoma cells, both $\alpha$-TP and $\alpha$-TT induced the reduction of total cholesterol as well as free cholesterol. Since $\alpha$-TP achieved a more marked reduction of total cholesterol than free cholesterol, a link between this cholesterol-lowering effect and cholesterol esters is implied [28].

Aside from the modulation of de novo cholesterol synthesis at the protein level, vitamin E also affects gene transcription underlying cholesterol biosynthesis. Valastya et al. reported a reduction in the expression of genes responsible for cholesterol biosynthesis in hepatocytes upon $\alpha$-TP treatment [19].

While all of the characteristics of vitamin E compounds discussed so far are indirectly neuroprotective due to the neurotoxic potential of inflammation [70] and oxidative stress [71,72], direct neuroprotective effects have also been described. In HT4 hippocampal cells, $\alpha$-TT but not $\alpha$-TP inhibited glutamate-induced pp 60 (c-Src) kinase activation and thereby cell death, with TTs being particularly potent [34]. Moreover, the modulation of 12-lipoxygenase, which also mediates glutamate-induced neurodegeneration, through $\alpha$-TT was described, suggesting a further route for $\alpha$-TT-mediated neuroprotection [35].

As such, epidemiological studies of patients aged 65 years or older reported that high dietary intake of vitamin $\mathrm{E}$ is inversely correlated with $\mathrm{AD}$ incidence. Interestingly, this effect was more pronounced with a combination of vitamin E compounds than with $\alpha$-TP alone [73]. However, in patients with mild cognitive impairment (MCI) or AD, $\alpha$-TP supplementation neither attenuated the progression of dementia nor improved cognitive function [12]. In comparison with donepezil, a standard therapy for symptomatic control of $\mathrm{AD}$, the supplementation of $2000 \mathrm{IU}$ vitamin $\mathrm{E}$ was of no benefit to patients with MCI, whereas donepezil was associated with a reduced progression of $\mathrm{AD}$ during the first 12 months of treatment [74]. A closer look into the bioavailability and metabolism of vitamin $\mathrm{E}$ is warranted for a potential explanation of this translational roadblock.

In PD, high dietary vitamin E, intake was inversely correlated with the occurrence of $\mathrm{PD}$, independent of age or gender [11]. In a double-blind placebo-controlled trial with $60 \mathrm{PD}$ patients, the dietary intake of $1000 \mathrm{mg}$ omega-3-fatty acid and $400 \mathrm{IU}$ vitamin E led to an improvement in the unified Parkinson's disease rating stage (UPDRS), total antioxidant capacity and glutathione concentration compared to placebo. There was also a decrease in high-sensitivity C-reactive protein (hs-CRP) and favorable effects on markers of insulin metabolism [44]. However, a placebo-controlled clinical trial (deprenyl and tocopherol antioxidative therapy of parkinsonism (DARATOP)) treated patients with early PD with $10 \mathrm{mg} / \mathrm{d}$ depernyl and/or $2000 \mathrm{IU} / \mathrm{d}$ TP to investigate whether this supplementation strategy could extend the time until levodopa therapy is required. Depernyl displayed protective properties, whereas TP demonstrated no efficacy [45]. Interestingly, Fahn et al. reported an extension of 2.5 years to the time before requirement of levodopa therapy, due to the administration of $\alpha$-TP and ascorbate in patients with early PD [75]. Contrasting these observations with those of epidemiological studies, which indicate that vitamin $\mathrm{E}$ 
may well be of benefit in PD, the inconsistent results of the interventional studies may explain why it has so far not been successfully integrated into clinical practice [76,77].

Few studies have investigated vitamin $\mathrm{E}$ for other neurodegenerative disorders such as Huntington's disease (HD) or amyotrophic lateral sclerosis (ALS). There is evidence suggesting that the excessive activation of glutamate-gated ion channels followed by cell death through oxidative stress is the cause of HD pathogenesis [46]. Hence, the antioxidative properties of $\alpha$-TP may be beneficial for HD patients. However, the highdose treatment of $73 \mathrm{HD}$ patients with $\alpha$-TP demonstrated no overall effect on neurologic or neuropsychiatric symptoms, but a selective effect on neurological symptoms of patients with early HD [46].

Since vitamin E had favorable effects on the onset and progression of murine ALS, it was considered a treatment or additive therapy in the management of ALS [78]. In a double-blind, placebo-controlled study including 289 patients suffering from ALS for less than 5 years, the supplementation of $\alpha$-TP had no effect on the deterioration of function, as assessed by the modified Norris limb scale. However, patients receiving $\alpha$-TP were less likely to progress from state A to the more severe state B on the ALS Health State scale [48]. Another study investigating $\alpha$-TP as an add-on therapy to riluzol in ALS reported no significant effect regarding survival rates, calculated time to death, tracheostomy, or permanent assisted ventilation [47].

\section{Genetics in the Metabolism of Vitamin E}

The metabolism and therefore bioavailability of vitamin $\mathrm{E}$ can be influenced by various factors, such as interaction with other nutritional compounds or pharmaceutics [49], gender [79], age [80], and lifestyle [81]. Due to the inhomogeneous outcome of interventional studies, individual response to vitamin E supplementation was considered as a potential explanation. Genetic heterogeneity arising from single nucleotide polymorphisms (SNPs) as a determinant of vitamin E homeostasis emerged as a hypothesis. SNPs are variations of a single nucleotide in a genome that can influence the biological properties of the encoded protein when occurring in coding regions $[82,83]$. Döring et al. described SNPs associated with genes that have a role in vitamin E metabolism, with the following genes considered as possible targets of SNPs, based on their function: lipoproteinlipase ( $L P L)$, tocopherol $(\alpha)$ transfer protein (TTPA), tocopherol-associated protein (TAP), multidrug resistance protein $2(M R P 2)$, pregnane $\mathrm{X}$ receptor $(P X R)$, and the genes encoding cytochrome $P 450$ enzymes (CYP3A5, CYP3A4 and CYP4F2). In the exons of TTPA, TAP and CYP3A5, only a few coding SNPs (cSNP) were found. The cSNP frequency calculated was 503-837 bp per cSNP and is therefore not highly polymorphic. There is also a common SNP in TAP, which leads to an exchange of amino acids in the $\mathrm{N}$-terminal functional domain of the protein. In $L P L$, $M R P 2, P X R, C Y P 3 A 4$, and CYP4F2, CSNPs were reported with a range of $100 \mathrm{bp}$ per cSNP, constituting a high number of polymorphisms [84].

Several genome-wide and candidate gene association studies have since uncovered further SNPs in proteins involved in vitamin E absorption efficiency or catabolism. This includes SNPs in CYP4F2, the gene encoding for cytochrome P4504F2, which catabolizes vitamin $\mathrm{E}$, as well as scavenger receptor class $\mathrm{B}$ member 1 (SCARB1), which encodes scavenger receptor class $B$ member 1, a plasma membrane receptor for high-density-lipoprotein (HDL), and the apolipoprotein $A 1 / C 3 / A 4 / A 5$-gene cluster, which encodes for apolipoproteins that are associated with $\alpha$-TP status [85-87]. Borel et al. showed that the postprandial chylomicronic $\alpha$-TP response to TP-rich meals was highly variable among subjects. The interindividual variability in TP bioavailability was estimated at $81 \%$, to which 28 SNPs and 11 genes were identified to be potentially contributing. Since most vitamin E is transported from the intestine to the liver and other organs by chylomicrons, 7 genes were involved in the postprandial chylomicronic triacylglycerol response. The other 4 genes were associated with the chylomicronic-TP response. The authors further observed that the plasma TP-concentration was positively correlated with the chylomicronic $\alpha$-TP response to 
TP-rich meals, highlighting the importance of interindividual ability to respond to dietary tocopherol intake as an influential factor for $\alpha$-TP serum concentration [88].

$\alpha$-TTP plays an important role in vitamin E homeostasis [89]. Resultant from two SNPs in the TTPA gene are two variants, E141K and R59W, which are associated with ataxia due to vitamin E deficiency. They cause the reduced binding of $\alpha$-TP to $\alpha$-TTP in vitro, as the variants are located near the ligand-binding domain of TTPA [90]. These findings are in line with Wright et al., who showed an approximate 3\% lower baseline vitamin E plasma level associated with the TTPA $(-980 \mathrm{~T}>\mathrm{A})$ variant in the promotor region of TTPA [91]. Regarding vitamin E catabolism, cytochrome P450 plays a substantial role, as it catalyzes the initial step in the vitamin E- $\omega$-hydroxylase pathway, and notably contributes to vitamin E levels [92]. Bardowell et al. discovered two SNPs differently influencing enzyme activity. While the CYP4F2 W12G variant leads to increased activity of the enzyme towards TPs and TTs, the CYP4F2 V433M variant reduces enzyme activity for TPs, but not for TTs [93]. In a clinical trial comparing these genetic variants, the V433M genotype was associated with significantly higher plasma $\alpha$-TP levels after 48 weeks of vitamin E supplementation (pioglitazone versus vitamin $\mathrm{E}$ versus placebo for the treatment of non-diabetic patients with nonalcoholic steatohepatitis (PIVENS) study: $\mathrm{r}=20.35, p=0.004$ and treatment of nonalcoholic fatty liver disease in children (TONIC) study: $r=20.34, p=0.026$ ) [94].

\section{Vitamin E Can Fuel the Pathogenesis of Neurodegenerative Diseases}

Although vitamin E displays beneficial effects, not only in neurodegenerative disease, but also cancer, cardiovascular disease and infections, current evidence does not support vitamin E supplementation in the treatment or prevention of these diseases. This is due to inconsistent study results and the evidence that high-dose vitamin E supplementation ( $>400 \mathrm{U} / \mathrm{d}$ ) might increase all-cause mortality [13]. Since these studies often involve malnourished populations or combined vitamin $\mathrm{E}$ with other substances, it remains unclear whether or not this effect would be seen in a population that is not nutritionally deficient.

Mechanisms explaining increased all-cause mortality are still debated. However, a number of adverse effects have been observed for vitamin $\mathrm{E}$. Very high dosages of vitamin $\mathrm{E}$ (44 $\mathrm{mg} / \mathrm{kg}$ body weight) increased blood pressure in spontaneously hypertensive stroke prone (SHRSP) rats [95]. There was also a rise in: phosphorylated neurofilament $\mathrm{H}$ protein, a prognostic marker of neurological disorders [96] and acute ischemic stroke [97]; glial fibrillary acidic protein associated with AD [98]; and cathepsin D in the CNS [95]. A study investigating the neuroinflammatory response following ischemic stroke in $\alpha$-TTP-deficient mice treated with an $\alpha$-TP diet (1680 IU /d) observed an exacerbation of ischemic stroke injury, due to supraphysiological brain injury accompanied by an increase in markers of oxidative injury and neurodegeneration [99].

Regarding AD, Grimm et al. investigated the in vitro effect of $\alpha-, \gamma$ - and $\delta$-TP on the synthesis and degradation of amyloid $\beta(A \beta)$, a peptide aggregating in extracellular plaques and a key driver of $A D$ pathophysiology. Surprisingly, there was an increase in A $\beta$ synthesis after incubation of SH-Sy5Y APP cells with $10 \mathrm{mM}$ vitamin E over $24 \mathrm{~h}$ [100]. In contrast, Azzori et al. reported a reduction in A $\beta 42$ concentration in SH-SY5Y APP Swe cells, due to incubation with $\alpha$ - and $\gamma$-TP [101]. Since Grimm et al. used an antibody that detects the last 5 amino acids of $A \beta$, and thereby not only $A \beta 42$ but total $A \beta$, it may be that there is a distinct influence of vitamin $E$ compounds on different $A \beta$ forms. Further experiments by Grimm et al. highlighted that the increased $A \beta$ synthesis is also due to increased $\gamma$ - and $\beta$-secretase activity, especially through $\gamma$ - and $\delta$-TP. $\alpha$-TP increased the protein levels of presenilin 1, a component of gamma secretase. The expression of genes encoding compounds of $\beta$-secretase was increased in response to $\alpha$-TP [100].

In contrast, an in vivo study using mice showed no effect of vitamin $E$ on the expression of $\beta$-site of APP cleaving enzyme (BACE-1) or a disintegrin and metalloproteinase domain-containing protein 10 (ADAM-10) [102]. In another study, the same group was able to validate the findings of increased $A \beta$ synthesis through vitamin $E$ compound supplementation [28]. Here, $\alpha$-TP and $\alpha$-TT amplified A $\beta$ synthesis after incubation on SH-SH5Y 
cells. These effects were mild. However, given the long preclinical phase of AD, even a small change in pathogenesis could result in earlier manifestation of clinical symptoms. To test the influence of $\alpha$-TT on a non-AD in vitro model, Grimm et al. used SH-SY5Y WT cells. Surprisingly, there was an even more pronounced effect on A $\beta$ synthesis [28]. A possible explanation could be the increased substrate presence in SH-SY5Y APP cells, resulting in enhanced $A \beta$ degradation. Given that high $A \beta$ level sustained over a long period of time may increase $A \beta$ catabolism, unaltered $A \beta$ synthesis as observed by Arrozi et al. could be explained by the treatment period of over six months [101]. A study investigating TP levels in the human cortex observed an association between higher $\alpha$ - and $\gamma$-TP levels and lower total and activated microglia density in cortical regions, suggesting a microglia-mediated beneficial effect on the slowly accumulating AD neuropathology [21]. In later stages of $\mathrm{AD}$, continued microglial activation can exacerbate tau pathology and negatively affect neurons and synapses $[103,104]$. During these stages, ameliorated microglial activation could be favorable. However, microglia activation may be protective in the early stages of $\mathrm{AD}$, as microglia clear soluble $\mathrm{A} \beta$, build protective barriers around $\mathrm{A} \beta$ plaques and remove debris $[105,106]$. Furthermore, a specific microglia cell type, disease-associated microglia (DAM), which has the potential to limit neurodegeneration, has been described [107]. Consequently, TPs being associated with reduced microglial activation highlights the possibility of further, perhaps adverse, effects of vitamin $\mathrm{E}$ supplementation on $\mathrm{AD}$, as the transition into DAM might be restricted. On the contrary, in vitamin E-deficient mice, RNA-sequencing of the spinal cord demonstrated the upregulation of genes associated with the innate immune response, indicating that microglial activation may result from tocopherol deficiency [108].

Overall, this underpins the need for the proper timing of vitamin E supplementation in the course of neurodegenerative disease to improve the outcomes of treatment and mitigate adverse effects (Figure 2).

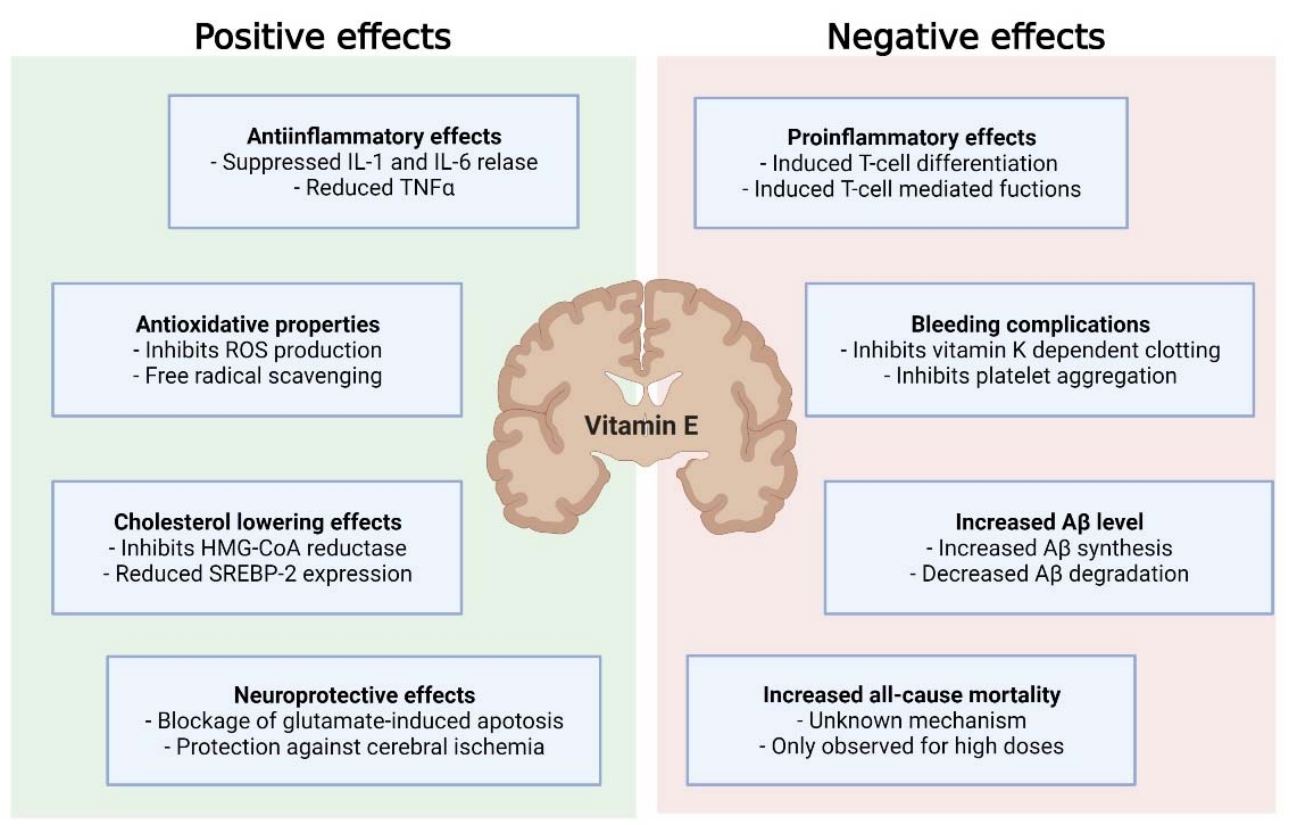

Figure 2. Positive and negative effects of vitamin E supplementation on neurodegenerative diseases. Abbreviations: IL-1, interleukin 1; IL-6, interleukin 6; TNF- $\alpha$, tumor necrosis factor $\alpha$; ROS, reactive oxygen species; HMG-CoA, $\beta$-Hydroxy- $\beta$-methylglutaryl-CoA; SREBP-2, sterol-regulytory-elementbinding-protein-2; $\mathrm{A} \beta$, Amyloid $\beta$.

\section{Is Vitamin E Supplementation Suitable for Everyone?}

Data from randomized controlled trials suggests that there are beneficial properties of vitamin $\mathrm{E}$ in neurodegenerative disease, as it is associated with a reduced risk of disease development and may slow disease progression [10]. However, due to inconsistent 
interventional trails that failed to validate the proposed favorable findings, vitamin $\mathrm{E}$ is not yet a part of the treatment or prevention of these disorders [109]. In addition, the evidence suggesting high-dose vitamin $\mathrm{E}$ may increase all-cause mortality warrants further caution $[13,110]$. Clearly, vitamin $\mathrm{E}$ is not suitable as a therapy that is to be used indiscriminately. However, in the current scientific landscape, the beneficial effects of vitamin E supplementation seem to outweigh the possible adverse effects, the latter to be considered for individual cases. As already discussed for $\mathrm{AD}$, vitamin $\mathrm{E}$ has been shown to increase $\mathrm{A} \beta$-synthesis in an in vitro $\mathrm{AD}$ model [28].

Due to its anti-inflammatory, antioxidative and cholesterol-lowering properties, vita$\min \mathrm{E}$ is considered a suitable therapeutic or preventive strategy. In line with the framework of personalized medicine, it could be argued that patients with a high inflammatory response, cholesterol levels or the occurrence of oxidative stress may benefit from vitamin E supplementation. In contrast, patients with low cholesterol, minimal inflammatory burden and little oxidative stress may be adversely affected by supplementation. Regarding the effects of $\alpha$ - and $\gamma$-TP on activated microglial cell density [21], supplementation can lead to either desirable or detrimental effects, dependent on disease progression and method of administration.

When analyzing a patient's suitability for supplementation, not only metabolic status and disease progression need to be taken into consideration, but also comorbidities and comedication. Vitamin E inhibits vitamin K-dependent coagulation factors (II, VII, IX and $X$ ) in the presence of vitamin K deficiency, and thereby induces coagulopathy [111]. This indicates an increased bleeding risk in patients taking vitamin K-dependent anticoagulation. Considering that falls are common in the elderly [112] and patients with neurodegenerative diseases [113], hemorrhagic complications are of high importance.

Lastly, when evaluating vitamin E supplementation, the administered dose needs to be defined. There is no consistent recommendation for the daily intake of vitamin $\mathrm{E}$, as the recommended dietary allowance (RDA) is defined by different methods across countries. Furthermore, various individual factors influence the metabolism and thereby bioavailability of vitamin E (Figure 3) [49]. Considering the genetic polymorphisms in genes involved in the metabolism of vitamin $\mathrm{E}$, the recommended intake should be tailored to the patient's genetic profile.

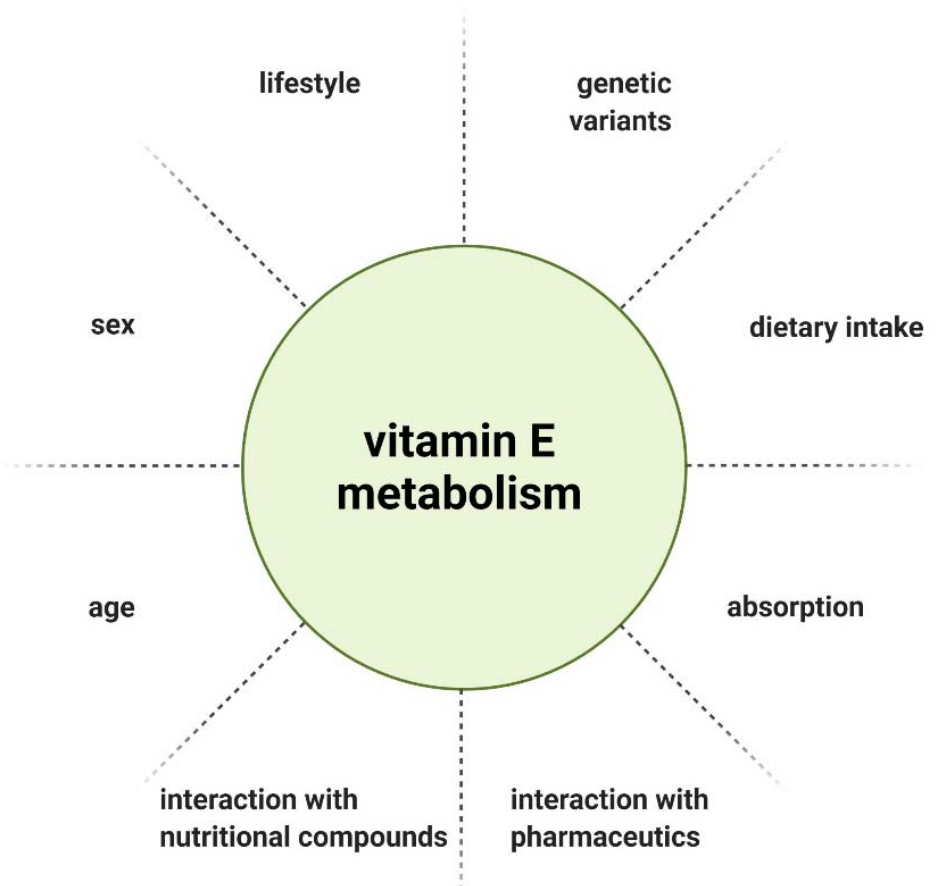

Figure 3. Factors influencing vitamin E metabolism. 


\section{Individualized, Proactive, Sustainable: The Future of Neuro-Nutrition}

For many chronic disorders, current healthcare outcomes are considered inadequate [114]. Neurodegenerative diseases affect millions of patients worldwide [115]. Personalized medicine is emerging as a focus point in healthcare, aiming not only for better treatment, but also prevention, in order to improve outcomes and reduce the prevalence of chronic disease [116]. In this regard, nutrition and its beneficial role in the prevention and delay of neurodegenerative disease onset has become tremendously important in recent years. There is compelling evidence that inflammation and oxidative stress lead to the onset of several chronic diseases, and that diet might help to postpone, prevent or modulate the progression of these disorders [117].

Foods rich in vitamin E-e.g., wheat germ oil [118], almonds, hazelnuts and walnuts -have demonstrated protective properties in AD [119]. The Mediterranean diet, which is characterized by a high intake of fruit, vegetables, monounsaturated fat, fish, wholegrains, legumes, and nuts, is associated with a reduction in the risk factors for $\mathrm{AD}$ and cognitive decline. However, evidence for other neurodegenerative disorders and for markers of neurodegeneration is lacking [120]. Further studies are needed to evaluate which dietary components carry the greatest responsibility for the demonstrated effect, since similar properties have been described for different nutrients.

Interventional studies in humans were unable to substantiate the promise of the therapeutic potential of vitamin $\mathrm{E}$ regarding neurodegenerative diseases, as observed in in vivo studies [10]. This failure may be due to interindividual differences in vitamin $\mathrm{E}$ metabolism. To overcome this roadblock, an in-depth understanding of the factors affecting vitamin E metabolism is necessary to improve treatment strategies and, ultimately, treatment outcomes (Figure 4) [121]. Personalization of vitamin E supplementation is likely to be expensive but, given the immense burden imposed by neurodegenerative disorders on healthcare systems locally and globally [115], harnessing the therapeutic potential of vitamin $\mathrm{E}$ appears to be a worthwhile pursuit for future studies.

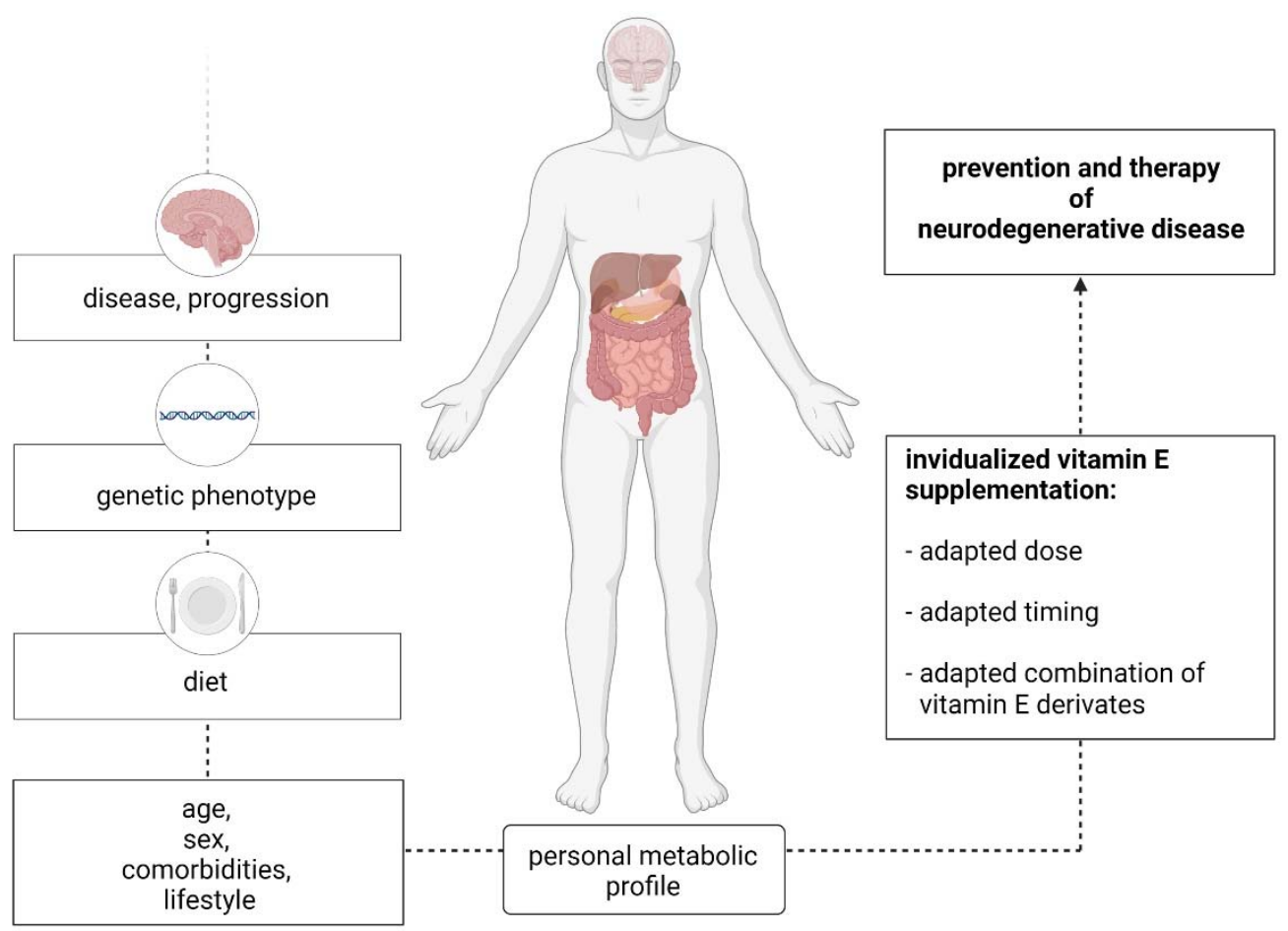

Figure 4. Individualized vitamin E supplementation and factors that should be considered beforehand. 
Author Contributions: Conceptualization, L.R.-N., S.G.M. and T.R.; writing-original draft preparation, L.R.-N. and C.N.; writing-review and editing, C.B.S., R.D. and T.W.; visualization, C.B.S.; supervision, S.G.M. All authors have read and agreed to the published version of the manuscript.

Funding: This research received no external funding.

Institutional Review Board Statement: Not applicable.

Informed Consent Statement: Not applicable.

Data Availability Statement: No new data were created or analyzed in this study. Data sharing is not applicable to this article.

Conflicts of Interest: The authors declare no conflict of interest.

\section{References}

1. Evans, H.M.; Bishop, K.S. On the existence of a hitherto unrecognized dietary factor essential for reproduction. Science 1922, 56, 650-651. [CrossRef]

2. Torquato, P.; Marinelli, R.; Bartolini, D.; Giusepponi, D.; Cruciani, G.; Siragusa, L.; Galarini, R.; Sebastiani, B.; Gioiello, A.; Galli, F. Chapter 24-Vitamin E: Metabolism and molecular aspects. In Molecular Nutrition; Patel, V.B., Ed.; Academic Press: Cambridge, MA, USA, 2020; pp. 487-518, ISBN 978-0-12-811907-5.

3. Chiroma, A.A.; Khaza'ai, H.; Abd Hamid, R.; Chang, S.K.; Zakaria, Z.A.; Zainal, Z. Analysis of Expression of Vitamin E-Binding Proteins in $\mathrm{H} 2 \mathrm{O} 2$ Induced SK-N-SH Neuronal Cells Supplemented with $\alpha$-Tocopherol and Tocotrienol-Rich Fraction. PLoS ONE 2020, 15, e0241112. [CrossRef] [PubMed]

4. Azzi, A. Many Tocopherols, One Vitamin E. Mol. Aspects Med. 2018, 61, 92-103. [CrossRef]

5. Azzi, A. Tocopherols, Tocotrienols and Tocomonoenols: Many Similar Molecules but Only One Vitamin E. Redox Biol. 2019, 26, 101259. [CrossRef]

6. Kemnic, T.R.; Coleman, M. Vitamin E Deficiency. In StatPearls; StatPearls Publishing: Treasure Island, FL, USA, 2021.

7. Muller, D.P.R. Vitamin E and Neurological Function. Mol. Nutr. Food Res. 2010, 54, 710-718. [CrossRef] [PubMed]

8. Finno, C.J.; Famula, T.; Aleman, M.; Higgins, R.J.; Madigan, J.E.; Bannasch, D.L. Pedigree Analysis and Exclusion of Alpha-Tocopherol Transfer Protein (TTPA) as a Candidate Gene for Neuroaxonal Dystrophy in the American Quarter Horse. J. Vet. Intern. Med. 2013, 27, 177-185. [CrossRef] [PubMed]

9. Kono, S.; Otsuji, A.; Hattori, H.; Shirakawa, K.; Suzuki, H.; Miyajima, H. Ataxia with Vitamin E Deficiency with a Mutation in a Phospholipid Transfer Protein Gene. J. Neurol. 2009, 256, 1180-1181. [CrossRef]

10. Bianchi, V.E.; Herrera, P.F.; Laura, R. Effect of Nutrition on Neurodegenerative Diseases. A Systematic Review. Nutr. Neurosci. 2019, 1-25. [CrossRef]

11. Schirinzi, T.; Martella, G.; Imbriani, P.; Di Lazzaro, G.; Franco, D.; Colona, V.L.; Alwardat, M.; Sinibaldi Salimei, P.; Mercuri, N.B.; Pierantozzi, M.; et al. Dietary Vitamin E as a Protective Factor for Parkinson's Disease: Clinical and Experimental Evidence. Front. Neurol. 2019, 10, 148. [CrossRef] [PubMed]

12. Farina, N.; Llewellyn, D.; Isaac, M.G.E.K.N.; Tabet, N. Vitamin E for Alzheimer's Dementia and Mild Cognitive Impairment. Cochrane Database Syst. Rev. 2017, 4, CD002854. [CrossRef]

13. Miller, E.R.; Pastor-Barriuso, R.; Dalal, D.; Riemersma, R.A.; Appel, L.J.; Guallar, E. Meta-Analysis: High-Dosage Vitamin E Supplementation May Increase All-Cause Mortality. Ann. Intern. Med. 2005, 142, 37-46. [CrossRef]

14. Galmés, S.; Serra, F.; Palou, A. Vitamin E Metabolic Effects and Genetic Variants: A Challenge for Precision Nutrition in Obesity and Associated Disturbances. Nutrients 2018, 10, 1919. [CrossRef]

15. Mohd Mutalip, S.S.; Ab-Rahim, S.; Rajikin, M.H. Vitamin E as an Antioxidant in Female Reproductive Health. Antioxidants 2018, 7, 22. [CrossRef]

16. Di Vincenzo, A.; Tana, C.; El Hadi, H.; Pagano, C.; Vettor, R.; Rossato, M. Antioxidant, Anti-Inflammatory, and Metabolic Properties of Tocopherols and Tocotrienols: Clinical Implications for Vitamin E Supplementation in Diabetic Kidney Disease. Int. J. Mol. Sci. 2019, 20, 5101. [CrossRef]

17. Wallert, M.; Ziegler, M.; Wang, X.; Maluenda, A.; Xu, X.; Yap, M.L.; Witt, R.; Giles, C.; Kluge, S.; Hortmann, M.; et al. $\alpha$-Tocopherol Preserves Cardiac Function by Reducing Oxidative Stress and Inflammation in Ischemia/Reperfusion Injury. Redox Biol. 2019, 26, 101292. [CrossRef]

18. Qureshi, A.A.; Burger, W.C.; Peterson, D.M.; Elson, C.E. The Structure of an Inhibitor of Cholesterol Biosynthesis Isolated from Barley. J. Biol. Chem. 1986, 261, 10544-10550. [CrossRef]

19. Valastyan, S.; Thakur, V.; Johnson, A.; Kumar, K.; Manor, D. Novel Transcriptional Activities of Vitamin E: Inhibition of Cholesterol Biosynthesis. Biochemistry 2008, 47, 744-752. [CrossRef]

20. Herbet, M.; Izdebska, M.; Piątkowska-Chmiel, I.; Gawrońska-Grzywacz, M.; Natorska-Chomicka, D.; Pawłowski, K.; Sysa, M.; Ślaska, B.; Dudka, J. $\alpha$-Tocopherol Ameliorates Redox Equilibrium and Reduces Inflammatory Response Caused by Chronic Variable Stress. BioMed Res. Int. 2018, 2018, e7210783. [CrossRef] 
21. de Leeuw, F.A.; Schneider, J.A.; Agrawal, S.; Leurgans, S.E.; Morris, M.C. Brain Tocopherol Levels Are Associated with Lower Activated Microglia Density in Elderly Human Cortex. Alzheimer Dement. 2020, 6, e12021. [CrossRef]

22. Ju, J.; Hao, X.; Lee, M.-J.; Lambert, J.D.; Lu, G.; Xiao, H.; Newmark, H.L.; Yang, C.S. A Gamma-Tocopherol-Rich Mixture of Tocopherols Inhibits Colon Inflammation and Carcinogenesis in Azoxymethane and Dextran Sulfate Sodium-Treated Mice. Cancer Prev. Res. 2009, 2, 143-152. [CrossRef]

23. Barve, A.; Khor, T.O.; Nair, S.; Reuhl, K.; Suh, N.; Reddy, B.; Newmark, H.; Kong, A.-N. Gamma-Tocopherol-Enriched Mixed Tocopherol Diet Inhibits Prostate Carcinogenesis in TRAMP Mice. Int. J. Cancer 2009, 124, 1693-1699. [CrossRef]

24. Abubakar, I.B.; Lim, K.-H.; Kam, T.-S.; Loh, H.-S. Enhancement of Apoptotic Activities on Brain Cancer Cells via the Combination of $\gamma$-Tocotrienol and Jerantinine A. Phytomedicine 2017, 30, 74-84. [CrossRef] [PubMed]

25. Lambert, J.D.; Lu, G.; Lee, M.-J.; Hu, J.; Ju, J.; Yang, C.S. Inhibition of Lung Cancer Growth in Mice by Dietary Mixed Tocopherols. Mol. Nutr. Food Res. 2009, 53, 1030-1035. [CrossRef]

26. Nor Azman, N.H.E.; Goon, J.A.; Abdul Ghani, S.M.; Hamid, Z.; Wan Ngah, W.Z. Comparing Palm Oil, Tocotrienol-Rich Fraction and $\alpha$-Tocopherol Supplementation on the Antioxidant Levels of Older Adults. Antioxidants 2018, 7, 74. [CrossRef]

27. Pearce, B.C.; Parker, R.A.; Deason, M.E.; Qureshi, A.A.; Wright, J.J. Hypocholesterolemic Activity of Synthetic and Natural Tocotrienols. J. Med. Chem. 1992, 35, 3595-3606. [CrossRef]

28. Grimm, M.O.W.; Regner, L.; Mett, J.; Stahlmann, C.P.; Schorr, P.; Nelke, C.; Streidenberger, O.; Stoetzel, H.; Winkler, J.; Zaidan, S.R.; et al. Tocotrienol Affects Oxidative Stress, Cholesterol Homeostasis and the Amyloidogenic Pathway in Neuroblastoma Cells: Consequences for Alzheimer's Disease. Int. J. Mol. Sci. 2016, 17, 1809. [CrossRef]

29. Chin, K.-Y.; Tay, S.S. A Review on the Relationship between Tocotrienol and Alzheimer Disease. Nutrients 2018, 10, 881. [CrossRef]

30. Malavolta, M.; Pierpaoli, E.; Giacconi, R.; Basso, A.; Cardelli, M.; Piacenza, F.; Provinciali, M. Anti-Inflammatory Activity of Tocotrienols in Age-Related Pathologies: A SASPected Involvement of Cellular Senescence. Biol. Proced. Online 2018, 20, 22. [CrossRef]

31. Gould, M.N.; Haag, J.D.; Kennan, W.S.; Tanner, M.A.; Elson, C.E. A Comparison of Tocopherol and Tocotrienol for the Chemoprevention of Chemically Induced Rat Mammary Tumors. Am. J. Clin. Nutr. 1991, 53, 1068S-1070S. [CrossRef]

32. Idriss, M.; Hodroj, M.H.; Fakhoury, R.; Rizk, S. Beta-Tocotrienol Exhibits More Cytotoxic Effects than Gamma-Tocotrienol on Breast Cancer Cells by Promoting Apoptosis via a P53-Independent PI3-Kinase Dependent Pathway. Biomolecules 2020, 10, 577. [CrossRef]

33. Sailo, B.L.; Banik, K.; Padmavathi, G.; Javadi, M.; Bordoloi, D.; Kunnumakkara, A.B. Tocotrienols: The Promising Analogues of Vitamin E for Cancer Therapeutics. Pharmacol. Res. 2018, 130, 259-272. [CrossRef]

34. Sen, C.K.; Khanna, S.; Roy, S.; Packer, L. Molecular Basis of Vitamin E Action. Tocotrienol Potently Inhibits Glutamate-Induced Pp60(c-Src) Kinase Activation and Death of HT4 Neuronal Cells. J. Biol. Chem. 2000, 275, 13049-13055. [CrossRef]

35. Khanna, S.; Roy, S.; Ryu, H.; Bahadduri, P.; Swaan, P.W.; Ratan, R.R.; Sen, C.K. Molecular Basis of Vitamin E Action: Tocotrienol Modulates 12-Lipoxygenase, a Key Mediator of Glutamate-Induced Neurodegeneration. J. Biol. Chem. 2003, 278, 43508-43515. [CrossRef] [PubMed]

36. Ren, Z.; Pae, M.; Dao, M.C.; Smith, D.; Meydani, S.N.; Wu, D. Dietary Supplementation with Tocotrienols Enhances Immune Function in C57BL/6 Mice. J. Nutr. 2010, 140, 1335-1341. [CrossRef]

37. Fukui, K. Neuroprotective and Anti-Obesity Effects of Tocotrienols. J. Nutr. Sci. Vitaminol. 2019, 65, S185-S187. [CrossRef]

38. Kumari, M.; Ramdas, P.; Radhakrishnan, A.K.; Kutty, M.K.; Haleagrahara, N. Tocotrienols Ameliorate Neurodegeneration and Motor Deficits in the 6-OHDA-Induced Rat Model of Parkinsonism: Behavioural and Immunohistochemistry Analysis. Nutrients 2021, 13, 1583. [CrossRef]

39. Frank, J.; Chin, X.W.D.; Schrader, C.; Eckert, G.P.; Rimbach, G. Do Tocotrienols Have Potential as Neuroprotective Dietary Factors? Ageing Res. Rev. 2012, 11, 163-180. [CrossRef]

40. Liu, X.; Gao, Z.; Fu, Q.; Song, L.; Zhang, P.; Zhang, X.; Hendrickson, H.; Crooks, P.A.; Zhou, D.; Zheng, G. Deuteration of the Farnesyl Terminal Methyl Groups of $\delta$-Tocotrienol and Its Effects on the Metabolic Stability and Ability of Inducing G-CSF Production. Bioorg. Med. Chem. 2020, 28, 115498. [CrossRef]

41. Lloret, A.; Badía, M.-C.; Mora, N.J.; Pallardó, F.V.; Alonso, M.-D.; Viña, J. Vitamin E Paradox in Alzheimer's Disease: It Does Not Prevent Loss of Cognition and May Even Be Detrimental. J. Alzheimer Dis. 2009, 17, 143-149. [CrossRef]

42. Dysken, M.W.; Sano, M.; Asthana, S.; Vertrees, J.E.; Pallaki, M.; Llorente, M.; Love, S.; Schellenberg, G.D.; McCarten, J.R.; Malphurs, J.; et al. Effect of Vitamin E and Memantine on Functional Decline in Alzheimer Disease: The TEAM-AD VA Cooperative Randomized Trial. JAMA 2014, 311, 33-44. [CrossRef] [PubMed]

43. Sano, M.; Ernesto, C.; Thomas, R.G.; Klauber, M.R.; Schafer, K.; Grundman, M.; Woodbury, P.; Growdon, J.; Cotman, C.W.; Pfeiffer, E.; et al. A Controlled Trial of Selegiline, Alpha-Tocopherol, or Both as Treatment for Alzheimer's Disease. The Alzheimer's Disease Cooperative Study. N. Engl. J. Med. 1997, 336, 1216-1222. [CrossRef]

44. Taghizadeh, M.; Tamtaji, O.R.; Dadgostar, E.; Daneshvar Kakhaki, R.; Bahmani, F.; Abolhassani, J.; Aarabi, M.H.; Kouchaki, E.; Memarzadeh, M.R.; Asemi, Z. The Effects of Omega-3 Fatty Acids and Vitamin E Co-Supplementation on Clinical and Metabolic Status in Patients with Parkinson's Disease: A Randomized, Double-Blind, Placebo-Controlled Trial. Neurochem. Int. 2017, 108, 183-189. [CrossRef] [PubMed]

45. Shoulson, I. DATATOP: A Multicenter Controlled Clinical Trial in Early Parkinson's Disease: Parkinson Study Group. Arch. Neurol. 1989, 46, 1052-1060. [CrossRef] 
46. Peyser, C.E.; Folstein, M.; Chase, G.A.; Starkstein, S.; Brandt, J.; Cockrell, J.R.; Bylsma, F.; Coyle, J.T.; McHugh, P.R.; Folstein, S.E. Trial of D-Alpha-Tocopherol in Huntington's Disease. Am. J. Psychiatry 1995, 152, 1771-1775. [CrossRef]

47. Graf, M.; Ecker, D.; Horowski, R.; Kramer, B.; Riederer, P.; Gerlach, M.; Hager, C.; Ludolph, A.C.; Becker, G.; Osterhage, J.; et al. High Dose Vitamin E Therapy in Amyotrophic Lateral Sclerosis as Add-on Therapy to Riluzole: Results of a Placebo-Controlled Double-Blind Study. J. Neural Transm. 2005, 112, 649-660. [CrossRef]

48. Desnuelle, C.; Dib, M.; Garrel, C.; Favier, A. A Double-Blind, Placebo-Controlled Randomized Clinical Trial of AlphaTocopherol (Vitamin E) in the Treatment of Amyotrophic Lateral Sclerosis. ALS Riluzole-Tocopherol Study Group. Amyotroph. Lateral Scler. Other Mot. Neuron Disord. 2001, 2, 9-18. [CrossRef]

49. Schmölz, L.; Birringer, M.; Lorkowski, S.; Wallert, M. Complexity of Vitamin E Metabolism. World J. Biol. Chem. 2016, 7, 14-43. [CrossRef] [PubMed]

50. Miyazawa, T.; Burdeos, G.C.; Itaya, M.; Nakagawa, K.; Miyazawa, T. Vitamin E: Regulatory Redox Interactions. IUBMB Life 2019, 71, 430-441. [CrossRef]

51. Fattoretti, P.; Malavolta, M.; Fabbietti, P.; Papa, R.; Giacconi, R.; Costarelli, L.; Galeazzi, R.; Paoloni, C.; Postacchini, D.; Lattanzio, F; et al. Oxidative Stress in Elderly with Different Cognitive Status: My Mind Project. J. Alzheimers Dis. 2018, 63, 1405-1414. [CrossRef] [PubMed]

52. Trist, B.G.; Hare, D.J.; Double, K.L. Oxidative Stress in the Aging Substantia Nigra and the Etiology of Parkinson's Disease. Aging Cell 2019, 18, e13031. [CrossRef]

53. Serbinova, E.; Kagan, V.; Han, D.; Packer, L. Free Radical Recycling and Intramembrane Mobility in the Antioxidant Properties of Alpha-Tocopherol and Alpha-Tocotrienol. Free Radic. Biol. Med. 1991, 10, 263-275. [CrossRef]

54. Simpson, D.S.A.; Oliver, P.L. ROS Generation in Microglia: Understanding Oxidative Stress and Inflammation in Neurodegenerative Disease. Antioxidants 2020, 9, 743. [CrossRef]

55. Lewis, E.D.; Meydani, S.N.; Wu, D. Regulatory Role of Vitamin E in the Immune System and Inflammation. IUBMB Life 2019, 71, 487-494. [CrossRef]

56. Elisia, I.; Kitts, D.D. Tocopherol Isoforms ( $\alpha-, \gamma_{-}^{-}$, and $\left.\delta_{-}\right)$Show Distinct Capacities to Control Nrf-2 and NfkB Signaling Pathways That Modulate Inflammatory Response in Caco-2 Intestinal Cells. Mol. Cell. Biochem. 2015, 404, 123-131. [CrossRef] [PubMed]

57. Jiang, Q.; Elson-Schwab, I.; Courtemanche, C.; Ames, B.N. Gamma-Tocopherol and Its Major Metabolite, in Contrast to AlphaTocopherol, Inhibit Cyclooxygenase Activity in Macrophages and Epithelial Cells. Proc. Natl. Acad. Sci. USA 2000, 97, 11494-11499. [CrossRef] [PubMed]

58. Saboori, S.; Shab-Bidar, S.; Speakman, J.R.; Yousefi Rad, E.; Djafarian, K. Effect of Vitamin E Supplementation on Serum C-Reactive Protein Level: A Meta-Analysis of Randomized Controlled Trials. Eur. J. Clin. Nutr. 2015, 69, 867-873. [CrossRef] [PubMed]

59. Asbaghi, O.; Sadeghian, M.; Nazarian, B.; Sarreshtedari, M.; Mozaffari-Khosravi, H.; Maleki, V.; Alizadeh, M.; Shokri, A.; Sadeghi, O. The Effect of Vitamin E Supplementation on Selected Inflammatory Biomarkers in Adults: A Systematic Review and Meta-Analysis of Randomized Clinical Trials. Sci. Rep. 2020, 10, 17234. [CrossRef]

60. Bouamama, S.; Merzouk, H.; Medjdoub, A.; Merzouk-Saidi, A.; Merzouk, S.A. Effects of Exogenous Vitamins A, C, and E and NADH Supplementation on Proliferation, Cytokines Release, and Cell Redox Status of Lymphocytes from Healthy Aged Subjects. Appl. Physiol. Nutr. Metab. 2017, 42, 579-587. [CrossRef]

61. Wang, Y.; Watson, R.R. Vitamin E Supplementation at Various Levels Alters Cytokine Production by Thymocytes during Retrovirus Infection Causing Murine AIDS. Thymus 1994, 22, 153-165.

62. Meydani, S.N.; Meydani, M.; Verdon, C.P.; Shapiro, A.A.; Blumberg, J.B.; Hayes, K.C. Vitamin E Supplementation Suppresses Prostaglandin E1(2) Synthesis and Enhances the Immune Response of Aged Mice. Mech. Ageing Dev. 1986, 34, 191-201. [CrossRef]

63. Klein, E.A.; Thompson, I.M.; Lippman, S.M.; Goodman, P.J.; Albanes, D.; Taylor, P.R.; Coltman, C. SELECT: The Selenium and Vitamin E Cancer Prevention Trial. Urol. Oncol. 2003, 21, 59-65. [CrossRef]

64. Buring, J.E.; Hebert, P.; Hennekens, C.H. The Alpha-Tocopherol, Beta-Carotene Lung Cancer Prevention Trial of Vitamin E and Beta-Carotene: The Beginning of the Answers. Ann. Epidemiol. 1994, 4, 75. [CrossRef]

65. Yang, C.S.; Luo, P.; Zeng, Z.; Wang, H.; Malafa, M.; Suh, N. Vitamin E and Cancer Prevention: Studies with Different Forms of Tocopherols and Tocotrienols. Mol. Carcinog. 2020, 59, 365-389. [CrossRef] [PubMed]

66. Suh, N.; Paul, S.; Lee, H.J.; Ji, Y.; Lee, M.-J.; Yang, C.S.; Reddy, B.S.; Newmark, H.L. Mixed Tocopherols Inhibit N-Methyl-NNitrosourea-Induced Mammary Tumor Growth in Rats. Nutr. Cancer 2007, 59, 76-81. [CrossRef]

67. Lu, G.; Xiao, H.; Li, G.-X.; Picinich, S.C.; Chen, Y.-K.; Liu, A.; Lee, M.-J.; Loy, S.; Yang, C.S. A $\gamma$-Tocopherol-Rich Mixture of Tocopherols Inhibits Chemically Induced Lung Tumorigenesis in A/J Mice and Xenograft Tumor Growth. Carcinogenesis 2010, 31, 687-694. [CrossRef]

68. Waniek, S.; Di Giuseppe, R.; Plachta-Danielzik, S.; Ratjen, I.; Jacobs, G.; Koch, M.; Borggrefe, J.; Both, M.; Müller, H.-P.; Kassubek, J.; et al. Association of Vitamin E Levels with Metabolic Syndrome, and MRI-Derived Body Fat Volumes and Liver Fat Content. Nutrients 2017, 9, 1143. [CrossRef]

69. Pearce, B.C.; Parker, R.A.; Deason, M.E.; Dischino, D.D.; Gillespie, E.; Qureshi, A.A.; Volk, K.; Wright, J.J. Inhibitors of Cholesterol Biosynthesis. 2. Hypocholesterolemic and Antioxidant Activities of Benzopyran and Tetrahydronaphthalene Analogues of the Tocotrienols. J. Med. Chem. 1994, 37, 526-541. [CrossRef]

70. Rehman, S.U.; Ali, T.; Alam, S.I.; Ullah, R.; Zeb, A.; Lee, K.W.; Rutten, B.P.F.; Kim, M.O. Ferulic Acid Rescues LPS-Induced Neurotoxicity via Modulation of the TLR4 Receptor in the Mouse Hippocampus. Mol. Neurobiol. 2019, 56, 2774-2790. [CrossRef] 
71. Nishimura, Y.; Kanda, Y.; Sone, H.; Aoyama, H. Oxidative Stress as a Common Key Event in Developmental Neurotoxicity. Oxidative Med. Cell. Longev. 2021, 2021, e6685204. [CrossRef]

72. Alzoubi, K.H.; Halboup, A.M.; Alomari, M.A.; Khabour, O.F. The Neuroprotective Effect of Vitamin E on Waterpipe Tobacco Smoking-Induced Memory Impairment: The Antioxidative Role. Life Sci. 2019, 222, 46-52. [CrossRef]

73. Morris, M.C.; Evans, D.A.; Tangney, C.C.; Bienias, J.L.; Wilson, R.S.; Aggarwal, N.T.; Scherr, P.A. Relation of the Tocopherol Forms to Incident Alzheimer Disease and to Cognitive Change. Am. J. Clin. Nutr. 2005, 81, 508-514. [CrossRef]

74. Petersen, R.C.; Thomas, R.G.; Grundman, M.; Bennett, D.; Doody, R.; Ferris, S.; Galasko, D.; Jin, S.; Kaye, J.; Levey, A.; et al. Vitamin E and Donepezil for the Treatment of Mild Cognitive Impairment. N. Engl. J. Med. 2005, 352, 2379-2388. [CrossRef]

75. Fahn, S.; Oakes, D.; Shoulson, I.; Kieburtz, K.; Rudolph, A.; Lang, A.; Olanow, C.W.; Tanner, C.; Marek, K. Parkinson Study Group Levodopa and the Progression of Parkinson's Disease. N. Engl. J. Med. 2004, 351, 2498-2508. [CrossRef]

76. Chi, D.S.; Gong, L.; Daigneault, E.A.; Kostrzewa, R.M. Effects of MPTP and Vitamin E Treatments on Immune Function in Mice. Int. J. Immunopharmacol. 1992, 14, 739-746. [CrossRef]

77. Odunze, I.N.; Klaidman, L.K.; Adams, J.D. MPTP Toxicity in the Mouse Brain and Vitamin E. Neurosci. Lett. 1990, 108, 346-349. [CrossRef]

78. Gurney, M.E.; Cutting, F.B.; Zhai, P.; Doble, A.; Taylor, C.P.; Andrus, P.K.; Hall, E.D. Benefit of Vitamin E, Riluzole, and Gabapentin in a Transgenic Model of Familial Amyotrophic Lateral Sclerosis. Ann. Neurol. 1996, 39, 147-157. [CrossRef] [PubMed]

79. Safari, T.; Miri, S.; Ghofran, O.; Fereidooni, F.; Niazi, A.A.; Bagheri, H.; Nematbakhsh, M. Gender Differences in Response to Vitamin E and C in Gentamicin Induced Nephrotoxicity in Wistar Rats. J. Nephropathol. 2017, 6, 338-345. [CrossRef]

80. Malik, A.; Eggersdorfer, M.; Trilok-Kumar, G. Vitamin E Status in Healthy Population in Asia: A Review of Current Literature. Int. J. Vitam. Nutr. Res. 2021, 91, 356-369. [CrossRef]

81. Alghadir, A.H.; Gabr, S.A.; Iqbal, Z.A.; Al-Eisa, E. Association of Physical Activity, Vitamin E Levels, and Total Antioxidant Capacity with Academic Performance and Executive Functions of Adolescents. BMC Pediatr. 2019, 19, 156. [CrossRef] [PubMed]

82. Wang, X.; Tomso, D.J.; Liu, X.; Bell, D.A. Single Nucleotide Polymorphism in Transcriptional Regulatory Regions and Expression of Environmentally Responsive Genes. Toxicol. Appl. Pharmacol. 2005, 207, 84-90. [CrossRef] [PubMed]

83. Zingg, J.-M.; Azzi, A.; Meydani, M. Genetic Polymorphisms as Determinants for Disease-Preventive Effects of Vitamin E. Nutr. Rev. 2008, 66, 406-414. [CrossRef]

84. Döring, F.; Rimbach, G.; Lodge, J.K. In Silico Search for Single Nucleotide Polymorphisms in Genes Important in Vitamin E Homeostasis. IUBMB Life 2004, 56, 615-620. [CrossRef]

85. Major, J.M.; Yu, K.; Chung, C.C.; Weinstein, S.J.; Yeager, M.; Wheeler, W.; Snyder, K.; Wright, M.E.; Virtamo, J.; Chanock, S.; et al. Genome-Wide Association Study Identifies Three Common Variants Associated with Serologic Response to Vitamin E Supplementation in Men. J. Nutr. 2012, 142, 866-871. [CrossRef]

86. Major, J.M.; Yu, K.; Wheeler, W.; Zhang, H.; Cornelis, M.C.; Wright, M.E.; Yeager, M.; Snyder, K.; Weinstein, S.J.; Mondul, A.; et al. Genome-Wide Association Study Identifies Common Variants Associated with Circulating Vitamin E Levels. Hum. Mol. Genet. 2011, 20, 3876-3883. [CrossRef] [PubMed]

87. Ferrucci, L.; Perry, J.R.B.; Matteini, A.; Perola, M.; Tanaka, T.; Silander, K.; Rice, N.; Melzer, D.; Murray, A.; Cluett, C.; et al. Common Variation in the Beta-Carotene 15,15'-Monooxygenase 1 Gene Affects Circulating Levels of Carotenoids: A GenomeWide Association Study. Am. J. Hum. Genet. 2009, 84, 123-133. [CrossRef] [PubMed]

88. Borel, P.; Desmarchelier, C.; Nowicki, M.; Bott, R.; Tourniaire, F. Can Genetic Variability in $\alpha$-Tocopherol Bioavailability Explain the Heterogeneous Response to $\alpha$-Tocopherol Supplements? Antioxid. Redox Signal. 2015, 22, 669-678. [CrossRef]

89. Peltzer, R.M.; Kolli, H.B.; Stocker, A.; Cascella, M. Self-Assembly of $\alpha$-Tocopherol Transfer Protein Nanoparticles: A Patchy Protein Model. J. Phys. Chem. B 2018, 122, 7066-7072. [CrossRef] [PubMed]

90. Bromley, D.; Anderson, P.C.; Daggett, V. Structural Consequences of Mutations to the $\alpha$-Tocopherol Transfer Protein Associated with the Neurodegenerative Disease Ataxia with Vitamin E Deficiency. Biochemistry 2013, 52, 4264-4273. [CrossRef]

91. Wright, M.E.; Peters, U.; Gunter, M.J.; Moore, S.C.; Lawson, K.A.; Yeager, M.; Weinstein, S.J.; Snyder, K.; Virtamo, J.; Albanes, D. Association of Variants in Two Vitamin e Transport Genes with Circulating Vitamin e Concentrations and Prostate Cancer Risk. Cancer Res. 2009, 69, 1429-1438. [CrossRef] [PubMed]

92. Parker, R.S.; Sontag, T.J.; Swanson, J.E.; McCormick, C.C. Discovery, Characterization, and Significance of the Cytochrome P450 Omega-Hydroxylase Pathway of Vitamin E Catabolism. Ann. N. Y. Acad. Sci. 2004, 1031, 13-21. [CrossRef] [PubMed]

93. Bardowell, S.A.; Stec, D.E.; Parker, R.S. Common Variants of Cytochrome P450 4F2 Exhibit Altered Vitamin E-\{omega\}Hydroxylase Specific Activity. J. Nutr. 2010, 140, 1901-1906. [CrossRef] [PubMed]

94. Athinarayanan, S.; Wei, R.; Zhang, M.; Bai, S.; Traber, M.G.; Yates, K.; Cummings, O.W.; Molleston, J.; Liu, W.; Chalasani, N. Genetic Polymorphism of Cytochrome P450 4F2, Vitamin E Level and Histological Response in Adults and Children with Nonalcoholic Fatty Liver Disease Who Participated in PIVENS and TONIC Clinical Trials. PLoS ONE 2014, 9, e95366. [CrossRef] [PubMed]

95. Miyamoto, K.; Shiozaki, M.; Shibata, M.; Koike, M.; Uchiyama, Y.; Gotow, T. Very-High-Dose $\alpha$-Tocopherol Supplementation Increases Blood Pressure and Causes Possible Adverse Central Nervous System Effects in Stroke-Prone Spontaneously Hypertensive Rats. J. Neurosci. Res. 2009, 87, 556-566. [CrossRef]

96. Lee, Y.; Lee, B.H.; Yip, W.; Chou, P.; Yip, B.-S. Neurofilament Proteins as Prognostic Biomarkers in Neurological Disorders. Curr. Pharm. Des. 2019, 25, 4560-4569. [CrossRef] [PubMed]

97. Hutanu, A.; Maier, S.; Bălaşa, R.; Oprea, O.; Barbu, S.; Septimiu, V.; Dobreanu, M. Plasma Phosphorylated Neurofilament Heavy Chains as a Potential Marker for Ischemic Stroke Patients. Rev. Romana Med. Lab. 2018, 26, 59-64. [CrossRef] 
98. Chatterjee, P.; Pedrini, S.; Stoops, E.; Goozee, K.; Villemagne, V.L.; Asih, P.R.; Verberk, I.M.W.; Dave, P.; Taddei, K.; Sohrabi, H.R.; et al. Plasma Glial Fibrillary Acidic Protein Is Elevated in Cognitively Normal Older Adults at Risk of Alzheimer's Disease. Transl. Psychiatry 2021, 11,1-10. [CrossRef]

99. Khanna, S.; Heigel, M.; Weist, J.; Gnyawali, S.; Teplitsky, S.; Roy, S.; Sen, C.K.; Rink, C. Excessive $\alpha$-Tocopherol Exacerbates Microglial Activation and Brain Injury Caused by Acute Ischemic Stroke. FASEB J. 2015, 29, 828-836. [CrossRef]

100. Grimm, M.O.W.; Stahlmann, C.P.; Mett, J.; Haupenthal, V.J.; Zimmer, V.C.; Lehmann, J.; Hundsdörfer, B.; Endres, K.; Grimm, H.S.; Hartmann, T. Vitamin E: Curse or Benefit in Alzheimer's Disease? A Systematic Investigation of the Impact of $\alpha-, \gamma-$ and $\delta$-Tocopherol on Aß Generation and Degradation in Neuroblastoma Cells. J. Nutr. Health Aging 2015, 19, 646-656. [CrossRef]

101. Pahrudin Arrozi, A.; Shukri, S.N.S.; Wan Ngah, W.Z.; Mohd Yusof, Y.A.; Ahmad Damanhuri, M.H.; Jaafar, F.; Makpol, S. Comparative Effects of Alpha- and Gamma-Tocopherol on Mitochondrial Functions in Alzheimer's Disease In Vitro Model. Sci. Rep. 2020, 10, 8962. [CrossRef]

102. Gaedicke, S.; Zhang, X.; Huebbe, P.; Boesch-Saadatmandi, C.; Lou, Y.; Wiswedel, I.; Gardemann, A.; Frank, J.; Rimbach, G. Dietary Vitamin E, Brain Redox Status and Expression of Alzheimer's Disease-Relevant Genes in Rats. Br. J. Nutr. 2009, 102, 398-406. [CrossRef] [PubMed]

103. Yoshiyama, Y.; Higuchi, M.; Zhang, B.; Huang, S.-M.; Iwata, N.; Saido, T.C.; Maeda, J.; Suhara, T.; Trojanowski, J.Q.; Lee, V.M.-Y. Synapse Loss and Microglial Activation Precede Tangles in a P301S Tauopathy Mouse Model. Neuron 2007, 53, 337-351. [CrossRef]

104. Salter, M.W.; Stevens, B. Microglia Emerge as Central Players in Brain Disease. Nat. Med. 2017, 23, 1018-1027. [CrossRef] [PubMed]

105. Hansen, D.V.; Hanson, J.E.; Sheng, M. Microglia in Alzheimer's Disease. J. Cell Biol. 2018, 217, 459-472. [CrossRef] [PubMed]

106. Kaur, D.; Sharma, V.; Deshmukh, R. Activation of Microglia and Astrocytes: A Roadway to Neuroinflammation and Alzheimer's Disease. Inflammopharmacology 2019, 27, 663-677. [CrossRef] [PubMed]

107. Keren-Shaul, H.; Spinrad, A.; Weiner, A.; Matcovitch-Natan, O.; Dvir-Szternfeld, R.; Ulland, T.K.; David, E.; Baruch, K.; Lara-Astaiso, D.; Toth, B.; et al. A Unique Microglia Type Associated with Restricting Development of Alzheimer's Disease. Cell 2017, 169, 1276-1290.e17. [CrossRef] [PubMed]

108. Finno, C.J.; Bordbari, M.H.; Gianino, G.; Ming-Whitfield, B.; Burns, E.; Merkel, J.; Britton, M.; Durbin-Johnson, B.; Sloma, E.A.; McMackin, M.; et al. An Innate Immune Response and Altered Nuclear Receptor Activation Defines the Spinal Cord Transcriptome during Alpha-Tocopherol Deficiency in Ttpa-Null Mice. Free Radic. Biol. Med. 2018, 120, 289-302. [CrossRef] [PubMed]

109. Lloret, A.; Esteve, D.; Monllor, P.; Cervera-Ferri, A.; Lloret, A. The Effectiveness of Vitamin E Treatment in Alzheimer's Disease. Int. J. Mol. Sci. 2019, 20, 879. [CrossRef]

110. Chai, W.; Maskarinec, G.; Franke, A.A.; Monroe, K.R.; Park, S.-Y.; Kolonel, L.N.; Wilkens, L.R.; Le Marchand, L.; Cooney, R.V. Association of Serum $\gamma$-Tocopherol Levels with Mortality: The Multiethnic Cohort Study. Eur. J. Clin. Nutr. 2020, 74, 87-96. [CrossRef]

111. Corrigan, J.J. The Effect of Vitamin E on Warfarin-Induced Vitamin K Deficiency. Ann. N. Y. Acad. Sci. 1982, 393, 361-368. [CrossRef]

112. Haagsma, J.A.; Olij, B.F.; Majdan, M.; van Beeck, E.F.; Vos, T.; Castle, C.D.; Dingels, Z.V.; Fox, J.T.; Hamilton, E.B.; Liu, Z.; et al. Falls in Older Aged Adults in 22 European Countries: Incidence, Mortality and Burden of Disease from 1990 to 2017. Inj. Prev. 2020, 26, i67-i74. [CrossRef]

113. Keleman, A.; Wisch, J.K.; Bollinger, R.M.; Grant, E.A.; Benzinger, T.L.; Morris, J.C.; Ances, B.M.; Stark, S.L. Falls Associate with Neurodegenerative Changes in ATN Framework of Alzheimer's Disease. J. Alzheimer Dis. 2020, 77, 745-752. [CrossRef] [PubMed]

114. Nardini, C.; Osmani, V.; Cormio, P.G.; Frosini, A.; Turrini, M.; Lionis, C.; Neumuth, T.; Ballensiefen, W.; Borgonovi, E.; D’Errico, G. The Evolution of Personalized Healthcare and the Pivotal Role of European Regions in Its Implementation. Personal. Med. 2021, 18, 283-294. [CrossRef] [PubMed]

115. Alzheimer's Association. Alzheimer's Disease Facts and Figures. Alzheimer Dement. 2021, 17, 327-406. [CrossRef]

116. Mathur, S.; Sutton, J. Personalized Medicine Could Transform Healthcare. Biomed. Rep. 2017, 7, 3-5. [CrossRef]

117. Lima, M.J.; Guiné, R.P.F. The Effect of Nutrition on Neurodegenerative Diseases. Adv. Health Dis. 2021, 40, $232-249$.

118. Yaseen, A.; Al-Okbi, S.; Hussein, A.; Mohamed, D.; Mohammad, A.A.; Fouda, K.; Mehaya, F.M. Potential Protection from Alzheimer's Disease by Wheat Germ and Rice Bran Nano-Form in Rat Model. J. Appl. Pharm. Sci. 2019, 9, 67-76.

119. Gorji, N.; Moeini, R.; Memariani, Z. Almond, Hazelnut and Walnut, Three Nuts for Neuroprotection in Alzheimer's Disease: A Neuropharmacological Review of Their Bioactive Constituents. Pharmacol. Res. 2018, 129, 115-127. [CrossRef]

120. Gardener, H.; Caunca, M.R. Mediterranean Diet in Preventing Neurodegenerative Diseases. Curr. Nutr. Rep. 2018, 7, 10-20. [CrossRef]

121. Cervantes, B.; Ulatowski, L.M. Vitamin E and Alzheimer's Disease-Is It Time for Personalized Medicine? Antioxidants 2017, 6, 45. [CrossRef] 